UDC 332.055

LBC 65.9 (2Poc) $8+65.050 .2$

\title{
EXPRESS ANALYSIS OF THE CONDITION OF THE ECONOMIC COMPLEX OF AN OLD INDUSTRIAL REGION
}

\author{
Inna V. Mitrofanova \\ Federal Research Center, Southern Scientific Center of the Russian Academy of Sciences, Rostov-on-Don; \\ Volgograd State University, Volgograd, Russian Federation

\section{Ekaterina V. Rodionova} \\ Volgograd Branch of Russian Presidential Academy of National Economy and Public Administration, \\ Volgograd, Russian Federation
}

\begin{abstract}
About $40 \%$ of the Russian regions are classified as old industrial ones, where due to a fragmentary character of the government regional policy in the 1990s, the main investment resources were concentrated in the enterprises of the old city forming industries that hindered the innovative development of these regions contrasted to their technological backwardness. That's why in the age when the industrial challenges emerge, the economic complexes of these regions are subject to risks, first of all, due to the threats and challenges connected with an intensive dynamics of the changes of exogenous and endogenous factors of the competitiveness of the production of basic industries.

The economy of old industrial regions is apt to depressions together with the deficit of financial resources, inefficient reforms, absence of relevant plants of the reindustrialization. In this connection, a quick analysis of the beginning of stagnation and depression plays a very important role. We suggest and test the methodology of an express analysis of the condition of the economic complex based on the calculation of an integral indicator, which takes into account the main industrial coefficients (labour productivity, efficiency of use of the fixed assets, intensity of the renovation of machines and equipment, dynamics of the fixed assets renovation, share of the investments into the gross regional products, investments into fixed capital and budgetary efficiency of fixed assets use), which allows for quick identification of the beginning of the stagnation and reducing the time lag between the problem perception and the correction of the regional economic policy. The regions of the Southern Federal District have been used as the example of old industrial regions.

In order to solve the problem of a depressive situation in a number of old industrial regions, an integrated State program for the efficient replacement in the old dominating industries of old enterprises by new modern plants within the national structural and industrial policy is indispensable. The leading role in their transformation is played with the modernization of the investment system, which fixes oan inertial scenario of the development, as well as its efficient replacement and efficient reindustrialization of the regional economic complex.

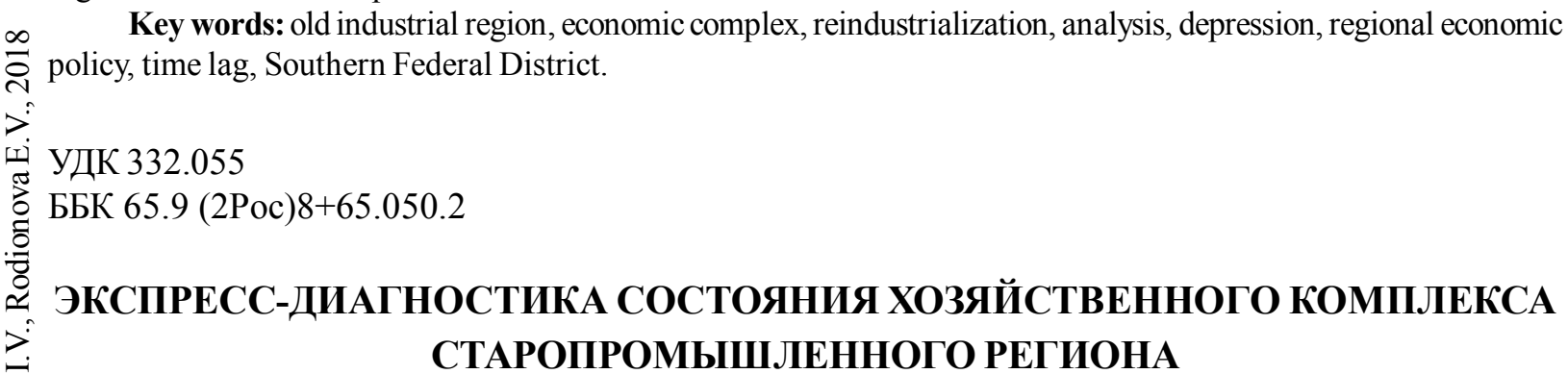

\author{
Инна Васильевна Митрофанова \\ Федеральный исследовательский центр Южный научный центр РАН, г. Ростов-на-Дону; \\ Волгоградский государственный университет, г. Волгоград, Российская Федерация
}




\section{Екатерина Владимировна Родионова}

Волгоградский филиал Российской академии народного хозяйства и государственной службы при Президенте Российской Федерации, г. Волгоград, Российская Федерация

Аннотация. Около 40 \% российских регионов относятся к типу старопромышленных, где вследствие фрагментарности государственной региональной политики в 90-х гг. ХХ века основные инвестиционные ресурсы сконцентрировались на предприятиях старопромышленных градообразующих отраслей, что замедлило инновационное развитие этих регионов на фоне консервации их технологической отсталости. Поэтому в эпоху индустриальных вызовов хозяйственные комплексы этих регионов в первую очередь подвергаются рискам из-за угроз и вызовов, спровоцированных интенсивной динамикой изменений экзогенных и эндогенных факторов конкурентоспособности продукции базовых отраслей.

Экономика старопромышленных регионов склонна к депрессиям на фоне дефицита финансовых ресурсов, неэффективного реформирования, отсутствия актуальных планов реиндустриализации. В связи с этим важную роль играет оперативная диагностика начала стагнации и депрессии.

Авторами предложена и апробирована на примере старопромышленных регионов Южного федерального округа методика экспресс-диагностики состояния хозяйственного комплекса, основанная на расчете интегрального индикатора с учетом основных производных показателей (производительность труда, эффективность использования ОПФ, интенсивность обновления средств труда, динамика обновления ОПФ, доля инвестиций в ВРП, инвестиции в основной капитал и бюджетная эффективность использования ОПФ), позволяющая оперативно выявлять начало его стагнации и сокращать временной лаг между осознанием проблемы и коррекцией региональной экономической политики.

Для решения проблемы депрессивного положения ряда старопромышленных регионов необходима комплексная государственная программа по эффективному замещению новыми современными производствами доминирующих старых индустрий в рамках национальной структурно-промышленной политики. В их трансформации определяющую роль играет модернизация системы инвестирования, которая может иметь своим прямым следствием как закрепление инерционного сценария развития, так и эффективное замещение, эффективную реиндустриализацию регионального хозяйственного комплекса.

Ключевые слова: старопромышленный регион, хозяйственный комплекс, реиндустриализация, диагностика, депрессия, региональная экономическая политика, временной лаг, Южный федеральный округ.

Old industrial region is a territory which has an "industrial nucleus" of the economic complex, and it is formed by the industries of the "third" and the "forth" technological modes. Such regions are referred to the group of adaptive territories which do not generate but rather adopt innovations $[10 ; 11]$.

In the age of industrial revolution, of the mass industrialization of the Russian economy, the old industrial regions (about $40 \%$ from the total number of the regions in Russia) developed mainly like the territories of the concentration of industrial production due to the serial construction of industrial plants usually as territorial and industrial complexes and very often in the limited monofunctional territories (mono-towns).

The direct negative consequence of an incosistent government regional policy which was realized in the 1990 s century was the concentration of the main investment resources of the state by old industries, which are city forming industries. This all had a negative impact on the structure of the industrial demand in the economy, it had a suppressive effect on the innovative development, it "fixed" the technological backwardness of such regions.

Today, in the post industrial times, these very regions were the first subject to risk due to threats and challenges caused by an intensive dynamics of changes of exogenous and endogenous factors of competitiveness of the production of basic industries. They are contrasted with the regions, which are maximally involved into the international trade for which a high labour productivity is typical. They have a developed service sector. The growth of the share of innovation products in the structure of the industrial production of the social and economic complex is observed in [1, pp. 161$163 ; 8$, pp. 50-52; 9, p. 14].

The prospects of their development are connected, first of all, with a traditional specialization which had been formed long before, 
and the vision of the future is determined by the trajectory of the preceeding dynamics. This fact mainly explains why most part of the strategies of social and economic development of old industrial regions of Russia are founded on conservative scenarios.

Old industrial regions of Russia are internally heterogeneous. Among them there are regions found at different stages of the evolutionary development. This fact is mainly determined by the specificity of the spatial localization. Old industrial regions can pass to a depressive state when the structural reforms, which started suffer from the deficit of financial resources, are planned irrationally. The reforms are realized inefficiently, that's why the priorities of the state regional social and economic policy should adequately take into account the available historic preconditions of the functioning of a territory. Its main advantages are determined by the level of the disposable social and economic potential and also by the functional role of the region in the provision of long-term social and economic interests of Russia.

In the strategic documents developed at the federal level of administration, the creation of innovatively active economy remains one of the main priorities. That's why old industrial regions of Russia will have to integrate into this process.

In order to choose a relevant complex of the tools of support of old industrial regions, their well-timed correction and change are needed. For that goal a quick, unsophisticated analysis is indispensable, which allows identifying the beginning of the damp, stagnation, transition to a crisis or a depression. Ideally, such a trend analysis (the study of the current social and economic situation in a region) is expected to give an objective assessment of the economic situation, to identify positive and negative tendencies of development, narrow places and growth points, constructive and destructive effects of the preceding administrative actions and other aspects, which are the basis for the explanation and the development of constructive measures for the future [15, pp. 9-11]. However, in the opinion of the authors, it is extremely important to develop and to test the labour saving methodology of the express analysis, which allows for quick identification of the beginning of stagnation and taking proactive operational measures.

The list of basic indices for the express analysis can be various. For instance, in compliance with the 'Methodology of a complex assessment of socio-economic development of Russian Regions' (2001) [4], an integrated index included 12 positions: GDP in a region per capita taking into account the purchasing parity standard; investments into fixed capital per capita; foreign trade turnover per capita; financial provision of a region taking into account the purchasing parity standard; share of the average stuffing number employed in small enterprises in the total average number of the employed in enterprises and organizations; registered unemployment rate; ratio of average income level to the minimum subsistence level; share of population with the incomes below minimum subsistence level in the total number of the population, etc.

According to other methodologies, the list should be enlarged to 18 positions due to the introduction of indices reflecting the results of the economic activity of the region and the size of disproportions between them.

Meanwhile, on the basis of the results of research by V. I. Volkov [16, pp. 176-178] and I. V. Mitrofanova $[5 ; 6]$, it is sufficient to control a small number of basic derived indices, the dynamics of which in total through the assessment of the change (growth, stability, decrease) of an integral express analysis allows identifying the beginning of the stagnation (slump, depression) of the economic complex of an old industrial region.

Any system is expected to have an integrating index providing a methodological unity of all its particular indices and identical evaluation of the level and the dynamics of the studied process. The development of an integrated (generalizing) indicator of the regional development has an important diagnostic function. The assessment of its dynamics reflects also the efficiency of the tools of the state regional policy realized in the region.

For the calculation of an integrated express indicator of the development of the economic complex of old industrial regions, the authors suggest using statistical and qualitative parameters (ratios), which are the key indicators for the evaluation of its condition (growth, stagnation, beginning of a depression): 
1) labour productivity (GDP / number of the employed in the regional economy ${ }^{1}$;

2) efficiency of use of fixed assets (GDP / value of fixed assets);

3 ) intensity of the renewal of productive equipment (investments into fixed assets / number of the employed in the regional economy);

4) dynamics of the renewal of fixed assets (investments into fixed assets / value of fixed assets);

5) investments into the GDP (investments into fixed assets / GDP);

6) budgetary efficiency of use of fixed assets (payments into the consolidated budget of Russia / value of the fixed assets).

By means of the adaptation and the development of the mathematical approaches used by T. A. Bondarskaya [2], taking into account the methodological approaches to the assessment of the level of social and economic development of the regions suggested by Yu. V. Zadorozhneva and A. E. Kalinina [17], M. A. Khalikov and D. V. Minin [3] and others, as well as the methodologies suggested in a number of official papers, the authors come to a conclusion that as particular key indices which characterize the condition of the economic complex of old industrial regions are heterogeneous, it is necessary to reduce them to summary values. At the reduction of specific indices into integrated one, the methods of the "sum of grades" and the "sum of ranks" which are founded on the use of various weight coefficients of the importance of specific indices (weights or shares), are used.

At the reduction of specific indices into an integrated one a famous method of relative differences is used (1):

$$
I=\frac{x-x_{\min }}{x_{\max }-x_{\min }},
$$

where $I$ - integrated index; $x$ - specific value of the index; $x_{\max }, x_{\min }-$ maximal and minimal values of the indices in a sample.

Then intermediary values of the coefficients with the help of equation (2) are calculated:

$$
K_{i j}=\frac{x_{i j}}{x_{j \max }}
$$

where $K_{i j}-j$ coefficient of region $i ; x_{i j}-j$ index of region $i ; x_{j \max }$ - maximal value of the $j$ coefficient among regions.

Intermediary coefficients are presented as a share from the maximal value of the corresponding index (1) in the regions.

The synthetic index constructed on the basis of the standardized values of basic indices is used as a generalized index $R j$ in equation (3):

$$
R_{j}=\sqrt{\sum\left(1-x_{i j}\right)^{2}}
$$

In accordance with the classification used by the Ministry of Regional Development of the Russian Federation and with the account of the specification of the authors, the Southern macroregion of Russia includes 2 basic old industrial regions (the Volgograd region and the Rostov region), 1 backing old industrial region (the Astrakhan region), 1 center of federal importance (the Krasnodar krai), 2 special regions (the Ingushetia Republic and the Chechen Republic), 1 depressive region (the Stavropol krai) and 6 depressive republics in a crisis situation.

In accordance with another classification (including mono-towns) suggested by State Company Stas Marketing, the Volgograd region is a service-oriented old industrial region; the Astrakhan region is a vulnerable old industrial region; the Rostov region is an old industrial region of the Soviet industrialization.

In the Volgograd region alone about $40 \%$ of the added value is produced in the industry, and this share is higher than in the rest of the regions of the Southern Federal District (Table 1).

The authors' operational methodology of the express analysis, which is based on the dynamic analysis of the changes of 6 basic economic indices (labour productivity, efficiency of use of fixed assets, intensity of the renewal of productive equipment, dynamics of the renewal of fixed assets, dynamics of the renewal of fixed assets, investments into the GDP, budgetary efficiency of use of fixed assets) will allow identifying quickly the beginning of the stagnation of the economic complex of an old industrial region and reducing the temporary lag between the perception of a problem, development and taking corresponding measures in the correction of the regional economic policy. 
Sectoral structure of the added value in the regions of the Southern macroregion in enlarged sectors in 2014, \%

\begin{tabular}{|l|c|c|c|c|c|}
\hline \multirow{2}{*}{$\begin{array}{c}\text { Regions } \\
\text { of the Southern macroregion }\end{array}$} & \multicolumn{5}{|c|}{ Sector } \\
\cline { 2 - 6 } & $\begin{array}{c}\text { Agrarian- } \\
\text { bioresource }\end{array}$ & $\begin{array}{c}\text { Raw } \\
\text { material }\end{array}$ & Industrial & $\begin{array}{c}\text { Trade and } \\
\text { financial }\end{array}$ & $\begin{array}{c}\text { Budgetary } \\
\text { dependent }\end{array}$ \\
\hline \multicolumn{5}{|c|}{ Southern federal district } \\
\hline Astrakhan region & 6,9 & 21,5 & 20,0 & 33,9 & 17,7 \\
\hline Volgograd region & $\mathbf{1 0 , 4}$ & $\mathbf{4 , 6}$ & $\mathbf{4 0 , 0}$ & $\mathbf{3 1 , 4}$ & $\mathbf{1 3 , 6}$ \\
\hline Krasnodar krai & 10,3 & 0,6 & 29,5 & 46,6 & 13,0 \\
\hline Rostov region & 12,3 & 0,9 & 30,2 & 41,0 & 15,6 \\
\hline Republic of Kalmykia & 14,0 & 0,7 & 26,2 & 36,3 & 22,8 \\
\hline Republic of Adygea & 14,0 & 0,7 & 26,2 & 36,3 & 22,8 \\
\hline Sevastopol & 5,4 & 0,0 & 12,1 & 40,2 & 42,3 \\
\hline Republic of Crimea & 22,0 & 3,1 & 16,9 & 30,9 & 27,1 \\
\hline \multicolumn{7}{|c|}{ North Caucasian federal district } \\
\hline Stavropol krai & 15,1 & 0,7 & 24,8 & 37,7 & 21,7 \\
\hline $\begin{array}{l}\text { Kabardino-Balkar } \\
\text { republic }\end{array}$ & 16,2 & 0,1 & 27,3 & 30,4 & 26,0 \\
\hline $\begin{array}{l}\text { Karachay-Cherkess } \\
\text { Republic }\end{array}$ & 19,2 & 1,5 & 29,7 & 22,2 & 27,4 \\
\hline Republic of Dagestan & 14,1 & 0,4 & 26,3 & 42,5 & 16,7 \\
\hline Republic of Ingushetia & 6,4 & 1,7 & 24,0 & 29,5 & 38,4 \\
\hline $\begin{array}{l}\text { Republic of } \\
\text { Ossetia-Alania }\end{array}$ & 15,6 & 0,3 & 22,4 & 32,1 & 29,6 \\
\hline Nhechen Republic & 7,2 & 1,7 & 20,0 & 32,6 & 38,5 \\
\hline
\end{tabular}

Source. Compiled on the basis of [7].

For a dynamic calculation of an integral express indicator of the assessment of the state of the economic complex of the old industrial regions of the Southern Federal District the open statistical data and their derivatives are used. (Table 2, 3).

On the basis of use of the methodological approaches presented earlier, the values of integral express indicators of the state of the economic complex of three old industrial regions of the Southern Federal District (the Astrakhan region, the Volgograd region and the Krasnodar krai) for a five year period are calculated (Table 4, Fig. 1).

On the basis of the suggested methodology using the data of the old industrial regions of the Southern Federal District, the beginning of the stagnation of the economic complex of the Volgograd region in the group of the most important 6 derived indices is identified. This trend began in 2013 at a multidirectional dynamics of each of them, but their integration demonstrates a downward movement of the express indicator in 2013-2015.
The methodology of the express analysis of the state of the economic complex tested on the information from the old industrial regions of the Southern Federal District takes into account an integral indicator of six main derived economic indices and allows identifying quickly the beginning of its stagnation and reducing the time lag between the problem perception and the correction of the regional economic policy.

The regional authorities of old industrial regions use an outdated industry as an economic basis, and without alternative jobs for people employed in it they are very often forced to formulate and to implement their own quasi governmental regional policy within poorly modernized, conservative strategies of the regional development.

Thus, the solution of the problem of a depressive state of a number of old industrial regions requires the development of the integrated governmental program for an efficient replacement of old dominating industries by new modern plants within the national structural and industrial policy. The leading role in their transformation is played by the investment 
system, which has as a direct consequence the fixation of an inertial scenario of development, conservation of the technological backwardness of a territory, an efficient replacement, an efficient reindustrialization of the regional economic complex.

Table 2

Basic indices of the development of the economic complex of the old industrial regions of the Southern Federal District (2011-2015)

\begin{tabular}{|c|c|c|c|c|c|c|}
\hline \multirow[t]{2}{*}{ Regions } & \multirow[t]{2}{*}{ Index } & \multicolumn{5}{|c|}{ Year } \\
\hline & & 2011 & 2012 & 2013 & 2014 & 2015 \\
\hline $\begin{array}{l}\text { Russian } \\
\text { Federation }\end{array}$ & \multirow{5}{*}{$\begin{array}{l}\text { GDP, } \\
\text { million } \\
\text { rubles }\end{array}$} & 45392276,7 & 49926068,7 & 54103000,3 & 58900652,2 & 64997039,3 \\
\hline $\begin{array}{l}\text { Southern Fe- } \\
\text { deral District }\end{array}$ & & 2777791,9 & 3185419,8 & 3574075,7 & 3920265,1 & 4304447,3 \\
\hline $\begin{array}{l}\text { Astrakhan } \\
\text { region }\end{array}$ & & 172616,6 & 273917,1 & 273917,1 & 288951,6 & 320735,0 \\
\hline $\begin{array}{l}\text { Volgograd } \\
\text { region }\end{array}$ & & 508433,3 & 607472,2 & 607472,2 & 715050,4 & 735293,1 \\
\hline $\begin{array}{l}\text { Rostov } \\
\text { region }\end{array}$ & & 765967,2 & 917689,1 & 917689,1 & 1000247,6 & 1171784,1 \\
\hline $\begin{array}{l}\text { Russian } \\
\text { Federation }\end{array}$ & \multirow{5}{*}{$\begin{array}{l}\text { Fixed } \\
\text { assets, } \\
\text { million } \\
\text { rubles }\end{array}$} & 108001247 & 121268908 & 133521531 & 147429656 & 160725261 \\
\hline $\begin{array}{l}\text { Southern Fe- } \\
\text { deral District }\end{array}$ & & 6548818 & 7222089 & 8347529 & 9255432 & 10342980 \\
\hline $\begin{array}{l}\text { Astrakhan } \\
\text { region }\end{array}$ & & 747640 & 808160 & 850132 & 912745 & 1053750 \\
\hline $\begin{array}{l}\text { Volgograd } \\
\text { region }\end{array}$ & & 1346669 & 1462441 & 1570668 & 1735392 & 1818202 \\
\hline Rostov region & & 1751414 & 1880446 & 2003572 & 2085372 & 2355619 \\
\hline $\begin{array}{l}\text { Russian } \\
\text { Federation }\end{array}$ & \multirow{5}{*}{$\begin{array}{l}\text { Invest- } \\
\text { ments } \\
\text { into fixed } \\
\text { assets, } \\
\text { million } \\
\text { rubles }\end{array}$} & 11035652 & 12586090 & 13450238 & 13902645 & 14555902 \\
\hline $\begin{array}{l}\text { Southern Fe- } \\
\text { deral District }\end{array}$ & & 1079284 & 1254958 & 1506034 & 1353827 & 1207473 \\
\hline $\begin{array}{l}\text { Astrakhan } \\
\text { region }\end{array}$ & & 69024 & 81665 & 122618 & 116856 & 111562 \\
\hline $\begin{array}{l}\text { Volgograd } \\
\text { region }\end{array}$ & & 104080 & 136154 & 140680 & 182798 & 193342 \\
\hline Rostov region & & 165978 & 207935 & 253623 & 264173 & 291029 \\
\hline $\begin{array}{l}\text { Russian } \\
\text { Federation }\end{array}$ & \multirow{5}{*}{$\begin{array}{l}\text { Average } \\
\text { annual } \\
\text { number } \\
\text { of the em- } \\
\text { ployed } \\
\text { in the } \\
\text { economy, } \\
\text { thousand } \\
\text { people }\end{array}$} & 67643,6 & 67968,3 & 67901,0 & 67813,3 & 68389,1 \\
\hline $\begin{array}{l}\text { Southern Fe- } \\
\text { deral District }\end{array}$ & & 6130,9 & 6201,1 & 6197,8 & 6161,2 & 6140,7 \\
\hline $\begin{array}{l}\text { Astrakhan } \\
\text { region }\end{array}$ & & 448,5 & 442,5 & 436,9 & 436,4 & 434,7 \\
\hline $\begin{array}{l}\text { Volgograd } \\
\text { region }\end{array}$ & & 1226,1 & 1252,9 & 1253,2 & 1230,3 & 1221,2 \\
\hline Rostov region & & 1902,2 & 1912,4 & 1913,6 & 1909,6 & 1901,8 \\
\hline $\begin{array}{l}\text { Russian } \\
\text { Federation, } \\
\text { billion rubles } \\
\end{array}$ & \multirow{5}{*}{$\begin{array}{l}\text { Payments } \\
\text { into the } \\
\text { consoli- } \\
\text { dated } \\
\text { budget } \\
\text { of the } \\
\text { Russian } \\
\text { Federa- } \\
\text { tion, mil- } \\
\text { lion rubles }\end{array}$} & 9719,6 & 10958,2 & 11325,9 & 12669,5 & 13787,8 \\
\hline $\begin{array}{l}\text { Southern Fe- } \\
\text { deral District }\end{array}$ & & 411108,6 & 486685,8 & 513260,0 & 559073,2 & 628886,0 \\
\hline $\begin{array}{l}\text { Astrakhan } \\
\text { region }\end{array}$ & & 30231,2 & 46729,8 & 47006,5 & 56745,6 & 68257,1 \\
\hline $\begin{array}{l}\text { Volgograd } \\
\text { region }\end{array}$ & & 92889,3 & 95265,9 & 103722,8 & 109750,4 & 118990,3 \\
\hline Rostov region & & 113867,8 & 133583,5 & 143452,4 & 160255,3 & 169132,4 \\
\hline
\end{tabular}

Source. Compiled on the basis of $[7 ; 12-14]$. 
Indices for the calculation of the integrated express indicator of the state of the economic complex of the old industrial regions of the Southern Federal District (2011-2015)

\begin{tabular}{|c|c|c|c|c|c|c|}
\hline Region & 2011 & 2012 & 2013 & 2014 & 2015 & 2016 \\
\hline \multicolumn{7}{|c|}{$\begin{array}{c}\text { Labour productivity } \\
\text { (GDP / number of the employed in the regional economy), rubles/person }\end{array}$} \\
\hline Russian Federation & 671050,6 & 734549,3 & 796792,4 & 868570,4 & 950400,6 & \\
\hline Southern Federal District & 453080,6 & 513686,2 & 576668,4 & 636282,7 & 700970,1 & \\
\hline Astrakhan region & 384875,4 & 473795,3 & 626956,1 & 662125,6 & 737830,7 & \\
\hline Volgograd region & 414675,2 & 456154,6 & 484736,8 & 581200,0 & 602107,0 & \\
\hline Rostov region & 402674,4 & 441100,3 & 479561,6 & 523799,5 & 616144,8 & \\
\hline \multicolumn{7}{|c|}{$\begin{array}{l}\text { Efficiency of u se of fixed assets } \\
\mathrm{P} / \text { value of fixed assets), rubles/ru }\end{array}$} \\
\hline Russian Federation & 0,42 & 0,41 & 0,41 & 0,39 & 0,40 & \\
\hline Southern Federal District & 0,42 & 0,44 & 0,43 & 0,42 & 0,42 & \\
\hline Astrakhan region & 0,23 & 0,26 & 0,32 & 0,32 & 0,30 & \\
\hline Volgograd region & 0,38 & 0,39 & 0,39 & 0,41 & 0,40 & \\
\hline Rostov region & 0,44 & 0,45 & 0,46 & 0,48 & 0,50 & \\
\hline \multicolumn{7}{|c|}{$\begin{array}{l}\text { In tensity of the renewal of productive equipment } \\
\text { d assets / number of the employed in the regional economy), rubles/person }\end{array}$} \\
\hline Russian Federation & 163,1 & 185,2 & 198,1 & 205,0 & 212,8 & \\
\hline Southern Federal District & 176,0 & 202,4 & 243,0 & 219,7 & 196,6 & \\
\hline Astrakhan region & 159,9 & 184,6 & 280,7 & 267,8 & 256,6 & \\
\hline Volgograd region & 84,9 & 108,7 & 112,3 & 148,6 & 158,3 & \\
\hline Rostov region & 87,3 & 108,7 & 132,5 & 138,3 & 153,0 & \\
\hline \multicolumn{7}{|c|}{$\begin{array}{l}\text { Dynamics of the renewal of fixed assets } \\
\text { (investments into fixed assets / value of fixed assets), rubles/rubles }\end{array}$} \\
\hline Russian Federation & 0,10 & 0,10 & 0,10 & 0,09 & 0,09 & \\
\hline Southern Federal District & 0,16 & 0,17 & 0,18 & 0,15 & 0,12 & \\
\hline Astrakhan region & 0,09 & 0,10 & 0,14 & 0,13 & 0,11 & \\
\hline Volgograd region & 0,08 & 0,09 & 0,09 & 0,11 & 0,11 & \\
\hline Rostov region & 0,09 & 0,11 & 0,13 & 0,13 & 0,13 & \\
\hline \multicolumn{7}{|c|}{$\begin{array}{c}\text { Share of investments into the GDP } \\
\text { (investments into fixed assets / GDP), rubles/rubles }\end{array}$} \\
\hline Russian Federation & 0,24 & 0,25 & 0,25 & 0,24 & 0,22 & \\
\hline Southern Federal District & 0,39 & 0,39 & 0,42 & 0,35 & 0,28 & \\
\hline Astrakhan region & 0,40 & 0,39 & 0,45 & 0,40 & 0,35 & \\
\hline Volgograd region & 0,20 & 0,24 & 0,23 & 0,26 & 0,26 & \\
\hline Rostov region & 0,22 & 0,25 & 0,28 & 0,26 & 0,25 & \\
\hline \multicolumn{7}{|c|}{$\begin{array}{l}\text { Budgetary efficiency of use of fixed assets } \\
\text { (payments into the consolidated budget of Russia / value of the fixed assets), rubles/rubles }\end{array}$} \\
\hline Russian Federation & 0,09 & 0,09 & 0,08 & 0,09 & 0,09 & \\
\hline Southern Federal District & 0,06 & 0,07 & 0,06 & 0,06 & 0,06 & \\
\hline Astrakhan region & 0,04 & 0,06 & 0,06 & 0,06 & 0,06 & \\
\hline Volgograd region & 0,07 & 0,07 & 0,07 & 0,06 & 0,07 & \\
\hline Rostov region & 0,07 & 0,07 & 0,07 & 0,08 & 0,07 & \\
\hline
\end{tabular}

Source. Compiled and calculated by the authors on the basis of the official statistics.

Table 4

Values of integral express indicators of the state of the economic complex of old industrial regions of the Southern Federal District in 2011-2015

\begin{tabular}{|l|c|c|c|c|c|}
\hline \multirow{2}{*}{\multicolumn{1}{|c|}{ Region }} & \multicolumn{5}{c|}{ Year } \\
\cline { 2 - 6 } & 2011 & 2012 & 2013 & 2014 & 2015 \\
\hline Russian Federation & 1,11 & 1,31 & 1,41 & 1,60 & 1,56 \\
\hline Southern Federal District & 0,98 & 1,01 & 1,26 & 1,35 & 1,54 \\
\hline Astrakhan region & 1,95 & 1,90 & 1,58 & 1,57 & 1,62 \\
\hline Volgograd region & 2,01 & 2,11 & 2,11 & 1,99 & 1,82 \\
\hline Rostov region & 1,89 & 1,97 & 1,71 & 1,73 & 1,72 \\
\hline
\end{tabular}

Source. Compiled and calculated by the authors. 


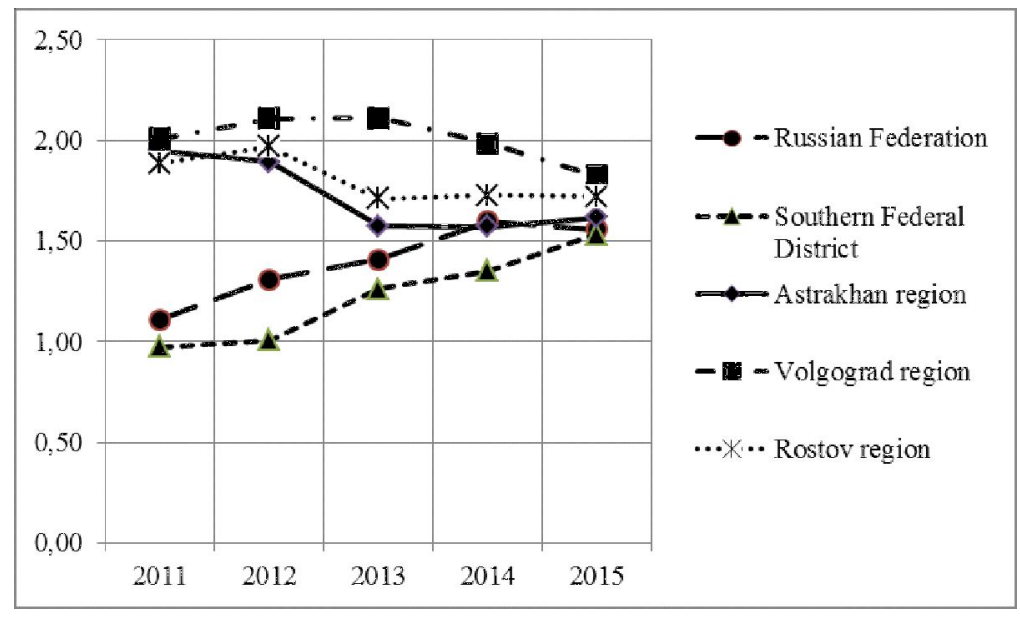

Fig. 1. Dynamics of integral express indicators of the state of the economic complex of old industrial regions of the Southern Federal District, 2011-2015

Source. Compiled and calculated by the authors.

\section{ACKNOWLEDGMENT}

The paper has been prepared in the context of the Program of fundamental research of the Presidium of the Russian Academy of Sciences I.52 "Provision of sustainable development of the South of Russia under the conditions of climatic, ecological and technology related challenges" (State assignment of the Southern Scientific Center of the Russian Academy of Sciences for 2018, project' state registration No. AAAA-A18118011990322-1.

\section{NOTE}

${ }^{1}$ The largest part of the methodologies takes into account the GRP (Gross Regional Product) per capita, although it is the employed people in the regional economy who produce the GRP.

\section{REFERENCES}

1. Bakanov S.A. «Kontseptsiya staropromyshlennykh regionov» $\mathrm{v}$ istorikoekonomicheskikh issledovaniyakh: problemy teorii $\mathrm{i}$ istoriografii ["The Conception of Old Industrial Regions" in Historical and Economic Research: Problems of Theory and Historiography]. Vestnik Chelyabinskogo gosudarstvennogo universiteta [Bulletin of Chelyabinsk State University], 2015, vol. 66, no. 24 (379), pp. 160-167.
2. Bondarskaya T.A. Metodika rascheta integralnogo pokazatelya razvitiya chelovecheskogo kapitala dlya formirovaniya kreativnoy sredy [Technique for Calculating an Integrated Indicator of Human Capital Development for Creative Environment Formation]. Sotsialno-ekonomicheskie yavleniya $i$ protsessy [Social and Economic Phenomena and Processes], 2015, vol. 10, no. 9, pp. 12-17.

3. Khalikov M.A., Minin D.V. Metodika kompleksnoy otsenki urovnya sotsialnoekonomicheskogo razvitiya regionov Rossiyskoy Federatsii i napravleniya ee sovershenstvovaniya [Methodology of an Integrated Assessment of SocioEconomic Development of Russian Regions and the Areas of Their Improvement]. Regionalnaya ekonomika: teoriya i praktika [Regional Economics: Theory and Practice], 2007, no. 7, pp. 59-63.

4. Metodika kompleksnoy otsenki urovnya sotsialno-ekonomicheskogo razvitiya subyektov Rossiyskoy Federatsii: Prilozhenie $k$ FTsP «Sokrashchenie razlichiy $v$ sotsialnoekonomicheskom razvitii regionov Rossiyskoy Federatsii (2002-2010 gg. i do 2015 g.): Postanovlenie Pravitelstva RF ot 11.10.2001g. № 717 [Methodology of a Complex Assessment of SocioEconomic Development of Russian Regions: The Annex to the Federal Target Program 'Reduction of Discrepancies in Socio-Economic Development of Russian Regions (2002-2010 and till 2015): Decree of the Government of the Russian Federation of October 11, 2001 No. 717]. URL: http://base.garant.ru/183843/.

5. Mitrofanova I.V., Kurchenkov V.V. Sovershenstvovanie sistemy pokazatelei sotsialnoekonomicheskogo razvitiya regiona $\mathrm{v}$ kontekste 
programmno-tselevogo upravleniya (na primere YuFO) [Improvement of the System of Regions' SocioEconomic Development Indicators in the Context of Program-Targeted Management (The Case of the Southern Federal District)]. Vestnik Voronezhskogo gosudarstvennogo universiteta. Seriya «Ekonomika i upravlenie» [Bulletin of Voronezh State University. Economics and Management], 2005, no. 2, pp. 57-67.

6. Mitrofanova I.V. Pokazateli regionalnogo razvitiya: rasshirennyy podkhod [The Indicators of Regional Development: Expanded Approach]. Osipov Yu.M., Sizov V.S., Zotova E.S., eds. Ekonomicheskaya teoriya v XXI veke. Vyp. 3(10): Problemy poreformennoy ekonomiki [Economic Theory in the $21^{\text {st }}$ Century. Iss. 3 (10): Problems of Post-Reform Economy]. Moscow, Ekonomist Publ., 2005, pp. 278-285.

7. Regiony Rossii. Sotsialno-ekonomicheskie pokazateli 2016. Stat. sbornik [Regions of Russia. Social and Economic Indicators of 2016. Book of Statistics]. Moscow, Rosstat Publ., 2016. 1326 p.

8. Shelomentseva V.P., Ifutina E.A., Shelomentsev P.Yu. Staropromyshlennyy region: priroda vozniknoveniya, klassifikatsiya, preobrazovanie [Old Industrial Region: Origin, Classification, Transformation]. Vestnik universiteta Turan [Bulletin of the Turan university], 2016, no. 2 (70), pp. 49-53.

9. Shestopalov A.G., Borisov E.I., Safronov K.K., Kaledina E.S. Perspektivy strategicheskogo razvitiya staropromyshlennykh regionov Rossii [The Prospects of Strategic Development of Old Industrial Regions of Russia]. Byudzhet [Budget], 2012, pp. 14-19.

10. Sorokina N.Yu. Klassifikatsiya staropromyshlennykh regionov dlya tseley upravleniya ustoychivym razvitiem [The Classification of Old Industrial Regions for Sustainable Development Management]. Izvestiya Tulskogo gosudarstvennogo universiteta. Ekonomicheskie i yuridicheskie nauki [News of the Tula State University. Economic and Legal Studies], 2013, vol. 3, iss. 1, pp. 257-268.
11. Sorokina N.Yu. Obespechenie ustoychivogo sotsialno-ekonomicheskogo razvitiya staropromyshlennykh regionov Rossiyskoy Federatsii: avtoref. diss. ... d-ra ekon. nauk [Ensuring Sustainable Social and Economic Development of Old Industrial Regions of the Russian Federation. Dr. econ. sci. abs. diss.]. Moscow, 2017. 40 p.

12. Sotsialno-ekonomicheskoe polozhenie Yuzhnogo federalnogo okruga v $2015 \mathrm{~g}$. [SocioEconomic Condition of the Southern Federal District in 2015]. Moscow, Federal State Statistics Service, 2016. 84 p.

13. Sotsialno-ekonomicheskoe polozhenie Yuzhnogo federalnogo okruga v 2016 g. [SocioEconomic Condition of the Southern Federal District in 2016]. Moscow, Federal State Statistics Service, $2017.83 \mathrm{p}$.

14. Sotsialno-ekonomicheskoe polozhenie Yuzhnogo federalnogo okruga v yanvare-dekabre 2016 g.: Inform.-anal. mat. [Socio-Economic Condition of the Southern Federal District in JanuaryDecember 2016: Data and Analytics]. Rostov-on-Don, Rostovstat Publ., 2017. 233 p.

15. Sutyagin V.S. O sootnoshenii nauchnykh prognozov i gosudarstvennykh programm sotsialnoekonomicheskogo razvitiya [On the Correlation of Scientific Forecasts and the State Programs of SocioEconomic Development]. Problemy prognozirovaniya [Problems of Forecasting], 1998, no. 1, pp. 3-11.

16. Volkov V.I. Novye podkhody k otsenke ekonomicheskogo razvitiya regionov [New Approaches to the Assessment of Regions' Economic Development]. Regionologiya [Regional Studies], 2003, no. 3, pp. 174-181.

17. Zadorozhneva Yu.V., Kalinina A.E. Mnogofaktornaya otsenka effektivnosti realizatsii sotsialno-ekonomicheskoy politiki regiona [MultipleFactor Assessment of Socio-Economic Policy of the Region]. Sovremennye problem nauki i obrazovaniya, 2012, no. 4. URL: http://www.science-education.ru/1046719.

\section{Information about the Authors}

Inna V. Mitrofanova, Doctor of Sciences (Economics), Professor, Leading Researcher, Federal Research Center, Southern Scientific Center of the Russian Academy of Sciences, Prosp. Chekhova, 41, 344006 Rostov-on-Don, Russian Federation; Professor of Department of Economic Theory, International and Regional Economics, Volgograd State University, Prosp. Universitetsky, 100, 400062 Volgograd, Russian Federation, mitrofanova@volsu.ru.

Ekaterina V. Rodionova, Assistant Lecturer, Department of Economics and Finance, Volgograd Branch of Russian Presidential Academy of National Economy and Public Administration, Gagarina St., 8, 400131 Volgograd, Russian Federation, rodionovaka1985@yandex.ru. 


\section{РЕГИОНАЛЬНАЯ ЭКОНОМИКА}

\section{Информация об авторах}

Инна Васильевна Митрофанова, доктор экономических наук, главный научный сотрудник, Федеральный исследовательский центр Южный научный центр РАН, просп. Чехова, 41, 344006 г. Ростов-на-Дону, Российская Федерация; профессор кафедры экономической теории, мировой и региональной экономики, Волгоградский государственный университет, просп. Университетский, 100, 400062 г. Волгоград, Российская Федерация, mitrofanova@volsu.ru.

Екатерина Владимировна Родионова, ассистент кафедры экономики и финансов, Волгоградский филиал Российской академии народного хозяйства и государственной службы при Президенте Российской Федерации, ул. Гагарина, 8, 400131 г. Волгоград, Российская Федерация, rodionovaka1985@yandex.ru. 